\title{
Pemanfaatan Tepung Ampas Kelapa Menjadi Produk Olahan Bernilai Jual untuk Meningkatkan Pendapatan Masyarakat Sungai Raden Kelurahan Handil Baru Kecamatan Samboja
}

\author{
Muhammad Munir Rendi Prastia* \\ Teknologi Hasil Perkebunan \\ Politeknik Pertanian Negeri \\ Samarinda \\ munirrandy@gmail.com \\ *Corresponding author
}

\author{
Noorcahyati \\ Balai Penelitian Teknologi \\ Konservasi Sumber Daya Alam \\ Samarinda \\ cahyati25@gmail.com
}

\author{
Farida Aryani \\ Teknologi Hasil Perkebunan \\ Politeknik Pertanian Negeri \\ Samarinda \\ ary_ani02@yahoo.com
}

\begin{abstract}
Abstrak----Sungai Raden merupakan salah satu wilayah yang berada di Kelurahan Handil Baru Kecamatan Samboja Kabupaten Kutai Kartanegara. Di daerah ini terdapat usaha perkebunan kelapa dalam hamparan yang cukup luas. Produk olahan kelapa dari perkebunan di Sungai Raden menghasilkan limbah ampas kelapa yang belum dimanfaatkan secara optimal. Limbah ampas kelapa memiliki kandungan serat pangan yang masih dapat digunakan sebagai produk olahan pangan yang potensial. Produk-produk yang dapat dikembangkan dengan memanfaatkan ampas kelapa adalah kerupuk, kue kering, dan abon ampas kelapa. Program Pengembangan Masyarakat (PPM) ini dilakukan pada bulan April 2021 dengan peserta sejumlah 10 orang. Metode yang dilakukan adalah penyampaian materi tentang kelapa, manfaat ampas kelapa, dan pemasaran produk serta dilanjutkan dengan pembuatan produk olahan dari ampas kelapa yaitu kerupuk, kue kering, dan abon. Secara umum pelatihan berjalan lancar. Hasil dari program ini adalah pemanfaatan limbah industri Virgin Coconut Oil (VCO) yang berupa ampas kelapa menjadi produk olahan yang memiliki nilai jual. Adanya peningkatan pengetahuan dan keterampilan masyarakat Sungai Raden dalam mengolah limbah industri VCO menjadi produk olahan yang bernilai jual dapat menjadi nilai tambah alternatif usaha bagi masyarakat setempat.
\end{abstract}

Kata kunci: Ampas, Kelapa, Kerupuk , Kue Kering, Abon, Sungai Raden.

\section{PENDAHULUAN}

Kelapa (Cocos nucifera) merupakan tanaman tropis yang telah lama dikenal oleh masyarakat Indonesia. Kelapa tersebar hampir di seluruh wilayah Nusantara. Tanaman kelapa merupakan salah satu komoditi tradisional Kalimantan Timur yang tumbuh dengan baik pada semua tempat yang diusahakan oleh masyarakat sebagai tanaman perkarangan maupun yang diusahakan dalam hamparan yang cukup luas. Usaha perkebunan kelapa rakyat memiliki hamparan yang luas hampir di seluruh wilayah Kalimantan Timur. Diantaranya terdapat di Kabupaten Kutai Kartanegara (Kecamatan Samboja dan Muara Jawa) dan Kabupaten Penajam Paser Utara (Kecamatan Penajam). Selain itu di beberapa daerah lainnya juga terdapat tanaman kelapa namun dalam ukuran yang masih terbatas. Luas areal kelapa rakyat di Kalimantan Timur tahun 2019 tercatat sebanyak 21.152 ha dengan jumlah produksi sebanyak 11.013 ton (Disbun Kaltim, 2020)

Kelapa yang dijuluki pohon kehidupan (tree of life) merupakan komoditas yang melimpah dan memiliki banyak sekali manfaat. Setiap bagian dari kelapa memiliki nilai kegunaan mulai dari akar, batang, bunga, buah, hingga daunnya. Akar kelapa berguna sebagai bahan baku pembuatan zat pewarna. Batang kelapa dapat digunakan untuk bahan baku perabotan rumah, mebel, maupun kayu bakar. Daun kelapa dapat digunakan sebagai bahan pembungkus atau dianyam untuk dijadikan atap rumah dan lidinya dapat digunakan untuk membuat sapu. Bagian bunga dapat dijadikan sebagai bahan baku pembuatan gula nira. Bagian buah terdiri dari kulit atau sabut, batok, daging kelapa dan air kelapa. Kulit buah atau sabut biasa digunakan sebagai bahan baku pembuatan keset, batok kelapa dapat dijadikan arang, daging buah kelapa dapat dikonsumsi atau diolah untuk diambil santannya sebagai bahan masakan dan minyak kelapa. Bahkan minyak kelapa telah diperdagangkan dari abad ke 17 dari Asia ke Eropa (Setiamidjaja, 2008). Air kelapa dapat dikonsumsi sebagai penghilang dahaga. Dari semua bagian kelapa yang mempunyai banyak kegunaan ini, terdapat salah satu hasil dari pengolahan kelapa yang kurang dimanfaatkan yaitu ampas kelapa. Untuk dapat dimanfaatkan, ampas kelapa dapat diolah menjadi tepung terlebih dahulu. Sehingga masa simpan ampas kelapa akan lebih lama ketika telah menjadi tepung serta dapat diolah menjadi berbagai produk olahan yang memiliki nilai jual.

Ampas kelapa merupakan limbah industri atau rumah tangga yang dihasilkan dari sisa proses pembuatan 
santan dari daging buah kelapa (Aryani dan Noorcahyati, 2021). Purawisastra (2001) menyatakan bahwa ampas kelapa mengandung serat galaktomanan sebesar $61 \%$ yang dapat menurunkan kadar kolesterol darah (Yamin, 2008). Hingga saat ini pemanfaatan ampas kelapa masih terbatas sebagai pakan ternak dan sebagian dijadikan sebagai makanan yaitu tempe bongkrek. Sementara itu, ampas kelapa memiliki kandungan serat kasar sekitar $15,07 \%$, protein $5,78 \%$, lemak $38,24 \%$, dan karbohidrat $33,64 \%$ (Putri, 2014).

Ampas kelapa merupakan hasil samping pengolahan kelapa yang mengandung serat. Serat pangan memiliki peranan penting dalam pencegahan resiko karsinogenesis dan aterosklerosis. Serat pangan juga dapat mengontrol pelepasan glukosa, membantu pengontrolan serta pengaturan diabetes melitus dan obesitas. Serat pangan dalam jumlah yang cukup di dalam makanan sangat baik untuk pencernaan dalam usus. Oleh karena itu, serat pangan sangat berperan dalam kesehatan dan kondisi penyakit di dalam berbagai kelompok populasi (Putri, 2014). Berdasarkan hasil analisis, ampas kelapa masih bernilai tinggi bila dimanfaatkan sebagai makanan berkadar lemak rendah yang cocok dikonsumsi oleh golongan konsumen yang kegemukan (obesitas), beresiko tinggi terhadap kolesterol dan jantung coroner (Putri, 2017).

Salah satu bentuk kegiatan untuk meningkatkan keterampilan masyarakat berbasis kewirausahaan dalam menyelesaikan suatu persoalan di daerahnya adalah dengan melaksanakan pemberdayaan masyarakat (Sujianto, 2019). Adanya kerja sama antara civitas akademika, institusi Penelitian dan Pengembangan pemerintah, instansi terkait dan masyarakat diharapkan dapat meningkatkan taraf hidup dan kesejahteraan masyarakat.

Sungai Raden Kelurahan Handil Baru merupakan salah satu daerah penghasil kelapa yang banyak menghasilkan limbah ampas kelapa hasil samping dari pembuatan VCO. Permasalahan yang dihadapi mitra adalah limbah ampas kelapa sangat melimpah namun hanya dijadikan pakan hewan ternak dan belum terserap sepenuhnya. Selain itu, masyarakat belum memahami cara pengolahan limbah ampas kelapa. Sebagai upaya dalam mengatasi permasalahan tersebut perlu adanya inovasi untuk memanfaatkan limbah ampas kelapa menjadi produk olahan pangan yang kaya akan serat dan bernilai jual.

\section{METODE PELAKSANAAN}

Program Pengembangan Masyarakat ini bertempat di Kelompok Usaha Bersama (KUB) Macan Dahan (Taman Bacaan dan Rumah Latihan) Sungai Raden RT.4, Kelurahan Handil Baru, Kecamatan Samboja. Kalimantan Timur. Waktu pelaksanaan kegiatan yaitu pada Senin, 12 April 2021 sampai dengan Selasa, 13 April 2021.

Kegiatan Program Pengembangan Masyarakat ini dilaksanakan dengan menggunakan metode ceramah, diskusi, dan praktik. Pada metode ceramah peserta pelatihan diberikan informasi dan wawasan mengenai pohon kelapa, manfaat dari ampas kelapa, peluang dan cara pemasaran produk. Agar terdapat interaksi yang baik dan peserta berperan aktif pada saat pelatihan, peserta diberikan kesempatan untuk bertanya serta mendiskusikan permasalahan yang berkaitan dengan usaha yang telah mereka rintis maupun hal-hal yang menjadi kendala dan hambatan dalam produksi dan pemasaran produk. Setelah kegiatan diskusi, peserta melakukan praktik langsung mengenai cara mengolah ampas kelapa menjadi tepung kelapa yang baik. Tepung ampas kelapa ini dapat digunakan sebagai bahan substitusi tepung terigu atau tepung lainnya untuk digunakan dalam pengolahan pangan (Nurhiyanah dan Septiani, 2019).

Setelah peserta mampu membuat tepung dari ampas kelapa, tahapan berikutnya adalah melakukan pembuatan produk berbahan dasar tepung ampas kelapa tersebut seperti kerupuk, abon serta kue kering.

Metode evaluasi yang digunakan adalah memberikan pertanyaan secara langsung kepada peserta dan peserta yang dapat menjawab pertanyaan tersebut akan diberikan hadiah kecil. Pertanyaan yang diberikan terkait dengan manfaat dari ampas kelapa dan materi yang telah disampaikan.

\section{HASIL DAN PEMBAHASAN}

Kegiatan pelatihan ini merupakan pelatihan untuk menggali potensi pengolahan kelapa khususnya limbah kelapa yang berupa ampas. Limbah ampas kelapa dari hasil produksi VCO masih dapat digunakan untuk diolah menjadi produk makanan yang kaya akan serat pangan. Produk makanan yang dapat dibuat dengan memanfaatkan limbah ampas kelapa adalah kerupuk, abon, dan kue kering. Pembuatan produk-produk makanan ini cukup sederhana dan dapat dilakukan dalam skala rumahan. Adanya alternatif pengolahan limbah ampas kelapa menjadi produk tepung yang bebas gluten dan kaya serat ini dapat menjadi solusi untuk mengurangi limbah hasil produksi dari VCO. Kegiatan pelatihan ini berlangsung dengan sangat kondusif meskipun di hari kedua pelatihan bertepatan dengan awal bulan Ramadhan. Para peserta sangat antusias dalam mengikuti kegiatan pelatihan, baik dalam penyampaian teori maupun praktik pembuatan produk. Kegiatan pelatihan diawali dengan pembukaan oleh perwakilan Pertamina Hulu Mahakam, Balai Penelitian Teknologi Konservasi Sumber Daya Alam (Balitek KSDA), Sekretaris Lurah Handil Baru, dan Narasumber. Penyampaian materi dilakukan oleh Narasumber dari Kampus Politani Samarinda dan perwakilan dari Balitek KSDA. Materi mencakup konsep pemberdayaan masyarakat, manfaat dan potensi limbah ampas kelapa, alat dan bahan serta cara pengolahan produk, pengemasan dan pemasaran produk. 


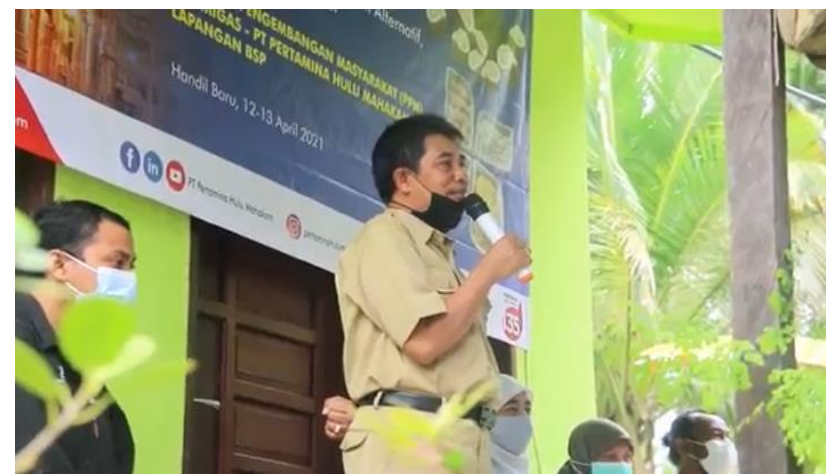

Gambar 1. Sambutan Oleh Sekretaris Lurah

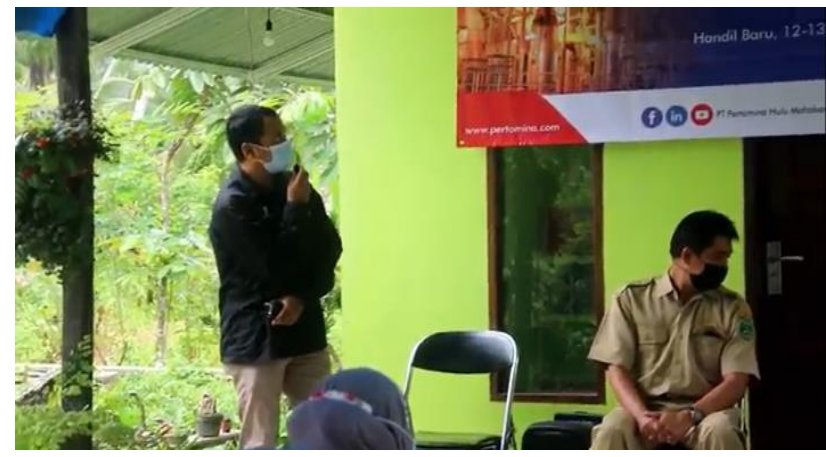

Gambar 2. Sambutan Oleh Pertamina Hulu Mahakam

Kemudian penyampaian materi dan dilanjutkan dengan sesi diskusi mengenai hal-hal yang telah disampaikan narasumber kepada para peserta. Selain itu dilakukan juga kegiatan kuis atau tes kepada para peserta.

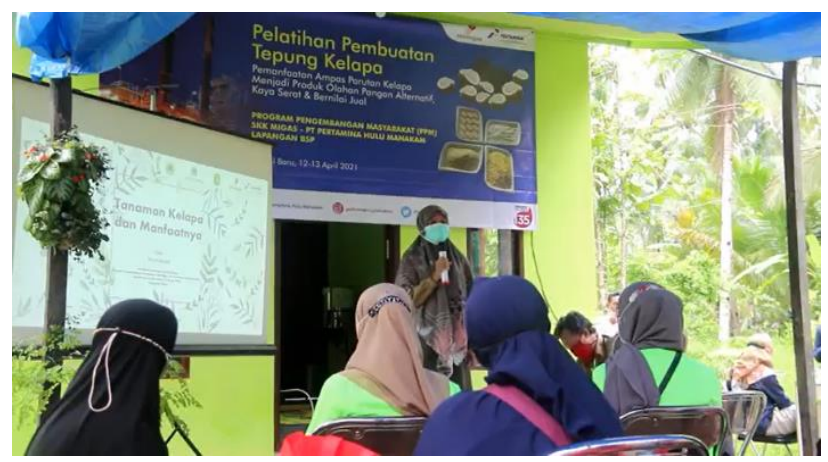

Gambar 3. Penyampaian Materi Oleh Balitek KSDA

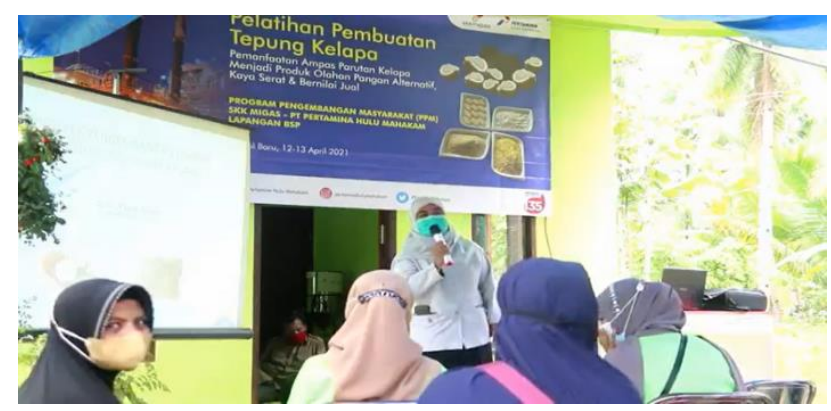

Gambar 4. Penyampaian Materi Oleh Dosen Politani Samarinda

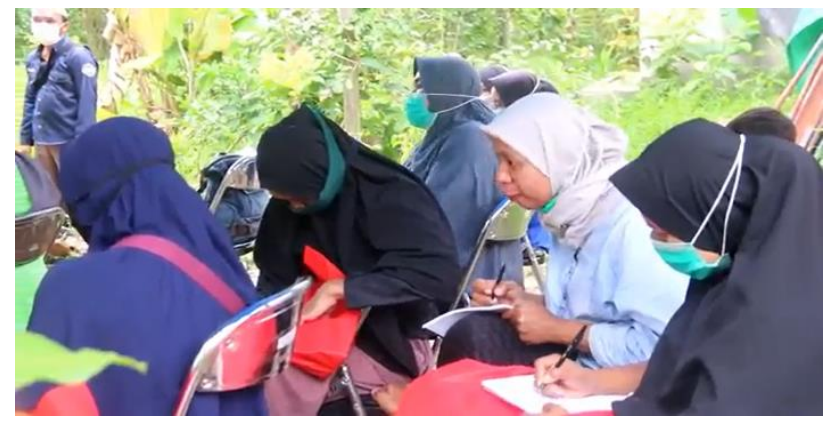

Gambar 5. Kuis atau Tes Untuk Peserta

Setelah kegiatan penyampaian teori, diskusi serta tes. Maka dilanjutkan dengan praktik pembuatan tepung ampas kelapa dan pembuatan produk.

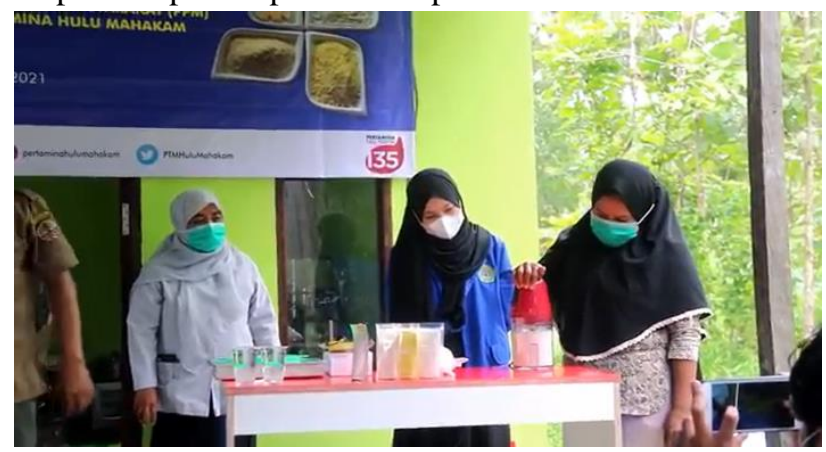

Gambar 6. Pembuatan Tepung Ampas Kelapa

Produk pertama yang dibuat dengan memanfaatkan ampas kelapa adalah kue kering. Bahan-bahan yang digunakan untuk pembuatan kue kering dari tepung ampas kelapa adalah sebagai berikut:

1. Gula 200 gram

2. Susu bubuk dancow vanilla 2 bungkus

3. Blueband 1 bungkus

4. Maizena 50 gram

5. Butter 100 gram

6. Tepung terigu 50 gram

7. Tepung ampas kelapa 200 gram

8. Telur 2 butir diambil kuningnya saja.

Adapun cara pembuatan kue kering dari tepung ampas kelapa ini adalah sebagai berikut:

1. Alat dan bahan disiapkan kemudian semua bahan ditimbang dengan menggunakan timbangan digital.

2. Bahan-bahan seperti gula, telur, margarin, butter, dan susu bubuk dicampur menggunakan mixer dengan kecepatan rendah selama 3 menit.

3. Kemudian setelah tercampur rata maka kecepatan mixer ditambah dan dicampurkan tepung maizena, tepung ampas kelapa dan tepung terigu ke dalamnya lalu diaduk hingga kalis.

4. Adonan yang sudah kalis kemudian dicetak bulatbulat diatas loyang dan dipipihkan menggunakan sendok dan garpu. 
5. Kemudian dimasukkan loyang yang berisi cetakan kue kering ke dalam oven dan dioven dengan menggunakan oven listrik dengan suhu $160^{\circ} \mathrm{C}$.

6. Jika kue kering sudah berwarna kuning kecoklatan, kue dapat dikeluarkan dari oven dan di dinginkan.

7. Pengemasan kue kering dapat menggunakan plastik dan divakum atau juga dapat menggunakan standing pouch.

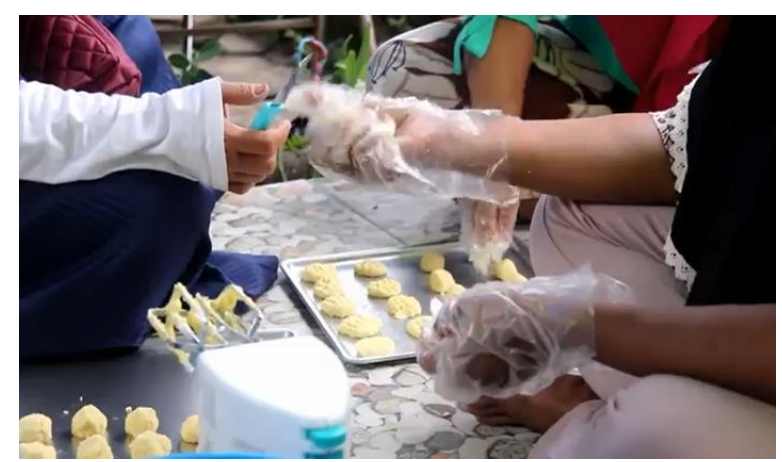

Gambar 7. Pembuatan Kue Kering Tepung Ampas Kelapa

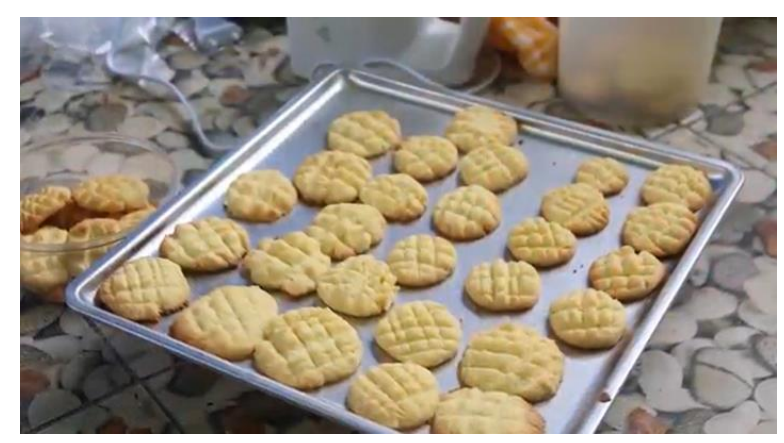

Gambar 8. Hasil Praktik Pembuatan Kue Kering Tepung Ampas Kelapa

Produk kedua yang dibuat dalam kegiatan pelatihan ini adalah abon tepung ampas kelapa. Bahan-bahan yang digunakan dalam pembuatan abon tepung ampas kelapa ini adalah sebagai berikut:

1. Tepung ampas kelapa 400 gram

2. Ikan layang 200 gram (opsional dapat juga memakai ayam)

3. Bawang putih 70 gram

4. Bawang merah 70 gram

5. Jahe 10 gram

6. Cabai 50 gram

7. Kemiri 20 gram

8. Ketumbar 20 gram

9. Lengkuas 20 gram

10. Gula 40 gram

11. Lada 10 gram

12. Serai 30 gram

13. Daun jeruk 5 gram

14. Daun salam 5 gram
Adapun cara pembuatan abon dari tepung ampas kelapa ini adalah sebagai berikut:

1. Semua alat dan bahan disiapkan.

2. Ikan layang dibersihkan dan direbus. Kemudian dipisahkan antara daging dan durinya.

3. Semua bumbu rempah yang telah dicuci bersih kemudian dihaluskan dengan blender.

4. Semua rempah disangrai hingga matang dan aromanya keluar.

5. Ikan yang telah disuwir dimasukkan ke dalam bumbu rempah dan dimasak.

6. Tepung ampas kelapa yang sebelumnya telah disangrai ditambahkan ke dalam bumbu dan ikan untuk dicampur dan disangrai.

7. Abon disangrai hingga matang kemudian dinginkan.

8. Abon yang telah dingin dapat dikemas menggunakan standing pouch atau kemasan yang vakum.

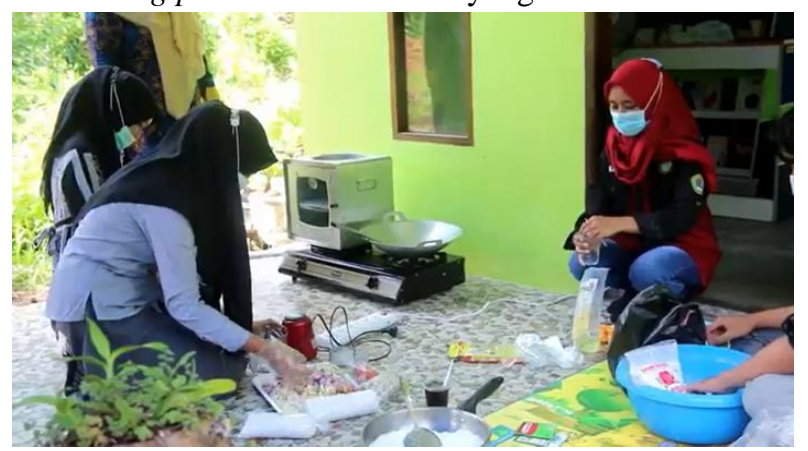

Gambar 9. Penghalusan Bumbu Abon

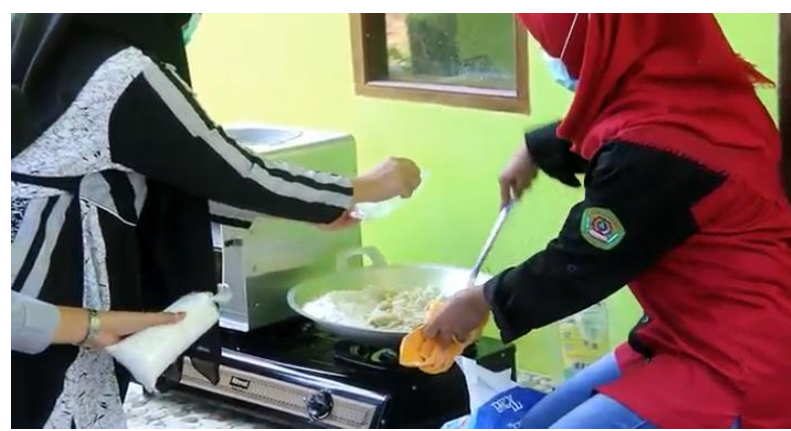

Gambar 10. Penyangraian Abon

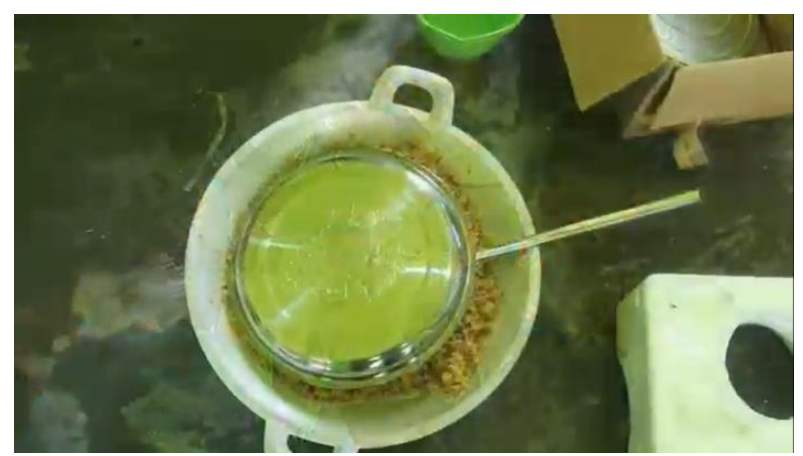

Gambar 11. Hasil Praktik Abon Tepung Ampas Kelapa 
Produk ketiga yang dibuat dalam kegiatan pelatihan ini adalah kerupuk tepung ampas kelapa. Bahan-bahan yang digunakan dalam pembuatan kerupuk tepung ampas kelapa ini adalah sebagai berikut:

1. Tepung ampas kelapa 150 gram

2. Tepung tepioka 500 gram

3. Bawang putih 50 gram

4. Ketumbar bubuk 10 gram

5. Masako ayam 9 gram

6. Garam dan air secukupnya

Adapun cara pembuatan kerupuk dari tepung ampas kelapa ini adalah sebagai berikut:

1. Alat dan bahan disiapkan

2. Tepung tapioka, tepung ampas kelapa dan bumbu lainnya ditimbang sesuai dengan kebutuhan resep.

3. Bawang putih dihaluskan dengan menggunakan blender.

4. Dicampurkan antara tepung tapioka, tepung ampas kelapa, bawang putih halus dan bumbu lainnya di dalam baskom. Kemudian ditambahkan air dan diaduk hingga adonan kalis.

5. Adonan kerupuk dimasukkan ke dalam plastik dan diikat. Adonan kerupuk direbus hingga plastik adonan naik ke permukaan.

6. Adonan kerupuk yang telah matang diangkat dari panci dan dinginkan.

7. Adonan kerupuk yang telah padat diiris tipis.

8. Irisan kerupuk disusun di atas tampah untuk dilakukan proses pengeringan dengan cara dijemur.

9. Kerupuk yang telah kering dapat digoreng dan dikemas menggunakan plastik vakum maupun toples.

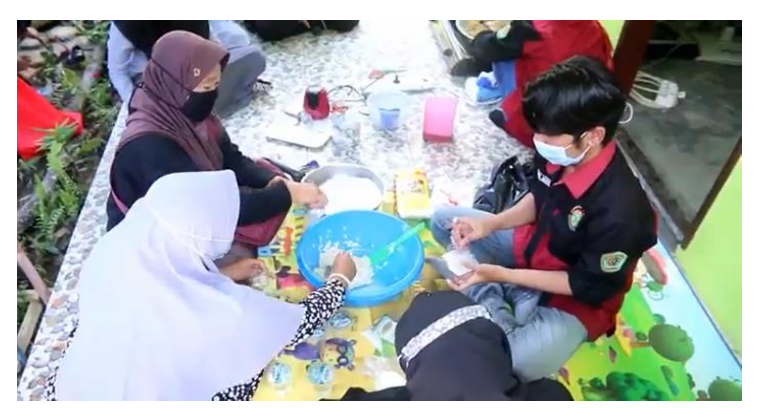

Gambar 12. Proses Pembuatan Kerupuk

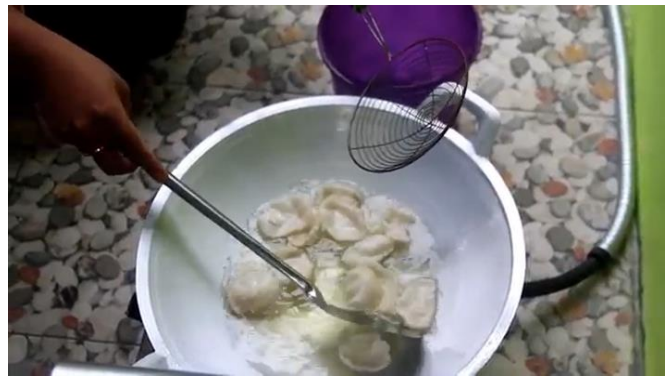

Gambar 13. Penggorengan Kerupuk Tepung Ampas Kelapa
Setelah semua praktik pembuatan produk telah dilakukan, para peserta mendapatkan sertifikat pelatihan dan bingkisan dari panitia. Kemudian dilanjutkan dengan acara penyerahan peralatan untuk pembuatan produk olahan tepung ampas kelapa yang dapat membantu proses produksi guna berjalannya usaha pembuatan produkproduk dari limbah ampas kelapa oleh panitia kepada ibuibu peserta pelatihan yang juga menjadi anggota KUB Macan Dahan di Sungai Raden RT.4. Acara terakhir adalah penutupan dan dilanjutkan dengan foto bersama.

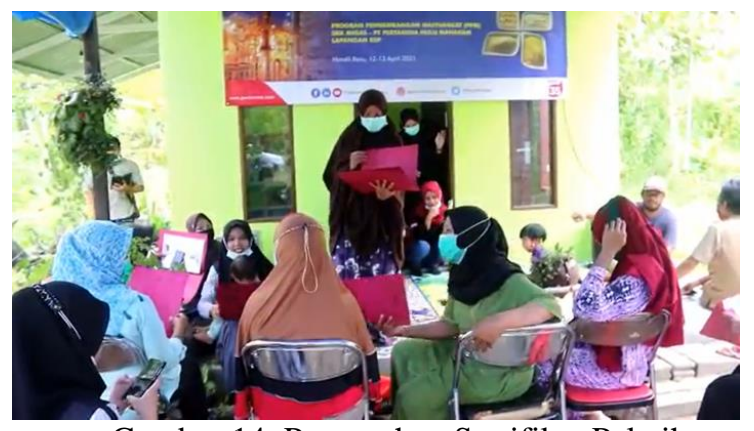

Gambar 14. Penyerahan Sertifikat Pelatihan

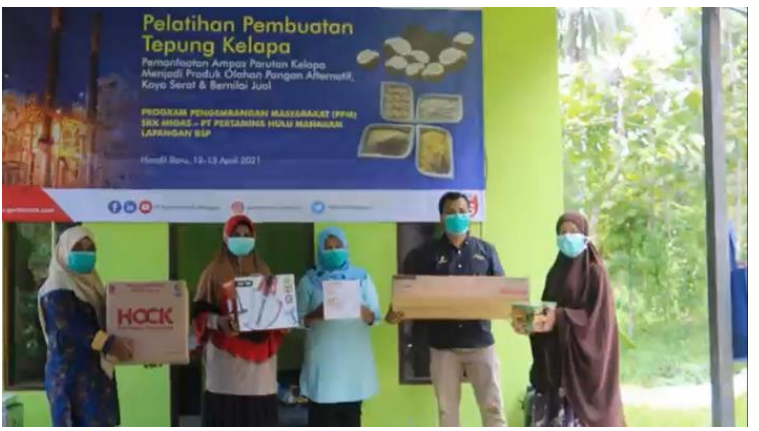

Gambar 15. Penyerahan Peralatan Produksi

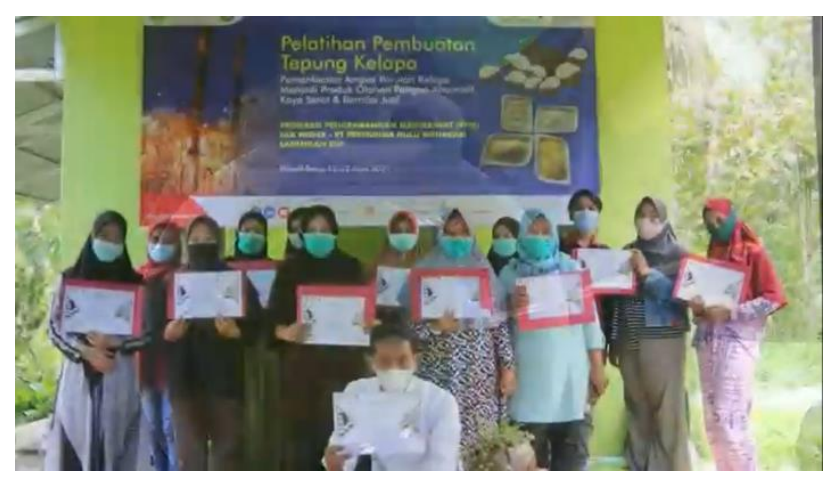

Gambar 16. Foto Bersama

\section{KESIMPULAN}

Kegiatan pelatihan yang telah dilakukan sebagai bagian dari pengabdian kepada masyarakat berupa transfer pengetahuan ini sangat membantu mengembangkan keterampilan dan kemampuan para peserta. Terlaksananya pelatihan ini juga membantu pemecahan masalah dalam pemanfaatan limbah ampas kelapa di daerah Sungai Raden RT.4, Kelurahan Handil Baru. Pembuatan berbagai produk yang memanfaatkan limbah ampas kelapa ini dapat meningkatkan penghasilan 
keluarga, ibu-ibu PKK, maupun masyarakat di daerah Sungai Raden. Adapun saran yang dapat diberikan setelah dilakukannya kegiatan pelatihan dan diskusi interaktif dengan para peserta yaitu perlu adanya pendampingan lebih lanjut agar usaha dapat berkembang dan berjalan mandiri, serta pelatihan dan pendampingan terkait pemasaran produk agar dapat dikenal oleh masyarakat luas dan menjadi salah satu oleh-oleh khas dari daerah Handil Baru. Selain itu, diperlukan pengelolaan keuangan yang tepat agar usaha dapat terus berjalan dan tidak berhenti setelah beberapa kali melakukan proses produksi. Peserta pelatihan disarankan untuk terus dapat berkreasi dengan berbagai produk olahan lainnya dari tepung ampas kelapa.

\section{UCAPAN TERIMA KASIH}

Ucapan terima kasih diucapkan kepada PT. Pertamina Hulu Mahakam dan Balai Penelitian Teknologi Konservasi Sumber Daya Alam (Balitek KSDA) yang telah menyelenggarakan kegiatan Program Pengembangan Masyarakat (PPM) serta memberikan bantuan pendanaan, Taman Bacaan dan Rumah Latihan (Macan Dahan) Sungai Raden RT.4 yang telah memfasilitasi tempat pelatihan. Kemudian terima kasih kepada Kelurahan Handil Baru yang mendukung acara pelatihan ini serta kampus Politani Samarinda yang bersedia membagi ilmu dan praktik nyata dalam pemanfaatan limbah ampas kelapa.

\section{DAFTAR PUSTAKA}

Aryani, F dan Noorcahyati. 2021. Pelatihan Pembuatan Tepung Kelapa. Pemanfaatan Ampas Parutan Kelapa Menjadi Produk Olahan Pangan Alternatif, Kaya Serat dan Bernilai Jual. Program Pengembangan Masyarakat SKK Migas PT Pertamina Hulu Mahakam.

Dinas Perkebunan Provinsi Kalimantan Timur. 2020. Kelapa Dalam. Kementrian Pertanian Direktorat Jendral Perkebunan. Kalimantan Timur.

Nurhiyanah dan Septiani. 2019. Substitusi Tepung Ampas Kelapa dalam Pembuatan Brownies Kukus Terhadap Sifat Organoleptik dan Nilai Gizi. Jurnal Gipas Vol 3 (2); 99-109. November 2019.

Putri, M. F. 2014. Kandungan Gizi dan Sifat Fisik Tepung Ampas Kelapa Sebagai Bahan Pangan Sumber Serat. Teknobuga. Vol 1. No 1: 32-41.

Putri, M.F. 2017. Pemanfaatan Tepung Ampas Kelapa Sebagai Sumber Serat Pangan dan Aplikasinya Pada Nugget Jamur Tiram. Jurnal Kesejahteraan Keluarga dan Pendidikan Vol 4. No 02: 77-85

Setyamidjaja, Djoehana. 2008. Bertanam Kelapa. Kanisius. Yogyakarta.

Sujianto, A. E. 2019. Pendidikan Kewirausahaan Melalui Pelatihan Produksi Tahu Dan Kerupuk Okara Bagi Ibu Rumah Tangga Desa Bendiljati Kulon Kabupaten Tulungagung. J-ADIMAS (Jurnal Pengabdian kepada Masyarakat) Vol 6. No 1. 